\%

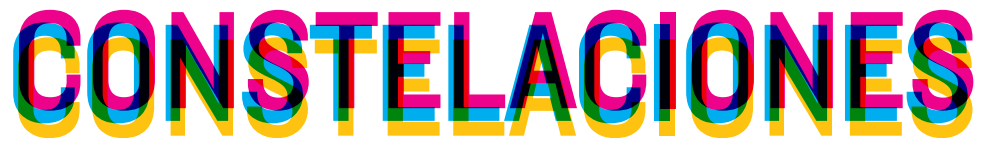

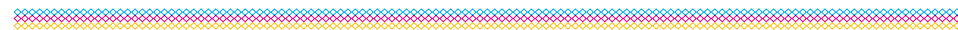


CONSTELACIONES n², mayo 2014

Revista de Arquitectura de la Universidad CEU San Pablo

Architecture Magazine of CEU San Pablo University

Periodicidad anual

Annual periodicity

COMITÉ DE REDACCIÓN EDITORIAL COMMITTEE

\section{Director Director}

Juan García Millán

Jefa de Redacción Editor in Chief

Covadonga Lorenzo Cueva

Secretario de Redacción Editorial Clerk

Rodrigo Núñez Carrasco

Maquetación y producción Design and production

María Fernández Hernández

Vocales Board Members

Fernando del Ama Gonzalo. Escuela Politécnica Superior, Universidad CEU San Pablo, Madrid

Pablo Campos Calvo-Sotelo. Escuela Politécnica Superior, Universidad CEU San Pablo, Madrid

Alfonso Díaz Segura Escuela Superior de Enseñanzas Técnicas, Universidad CEU Cardenal Herrera, Valencia

Mayka García Hípola. Escuela Politécnica Superior, Universidad CEU San Pablo, Madrid

Sonia Izquierdo Esteban. Escuela Politécnica Superior, Universidad CEU San Pablo, Madrid

Javier Sáenz Guerra. Escuela Politécnica Superior, Universidad CEU San Pablo, Madrid

\section{CONSEJO EDITORIAL EDITORIAL BOARD}

Beatriz Colomina. School of Architecture, Princeton University, New Jersey

Carmen Díez Medina. Escuela de Ingeniería y Arquitectura, Universidad de Zaragoza

María Antonia Frías Sargadoy. Escuela Técnica Superior de Arquitectura, Universidad de Navarra

Ángel González García. Facultad de Geografía e Historia, Universidad Complutense de Madrid

Juan Miguel Hernández Léon. Escuela Técnica Superior de Arquitectura, Universidad Politécnica de Madrid

Juan José Lahuerta Alsina. Escuela Técnica Superior de Arquitectura, Universidad Politécnica de Cataluña, Barcelona

Eduardo Leira Sánchez. Ex director del Plan General de Ordenación Urbana, Madrid

Joaquín Medina Wamburg. Facultad de Aquitectura Diseño y Urbanismo, Universidad de Buenos Aires

Zaida Muxí Martínez. Escuela Técnica Superior de Arquitectura, Universidad Politécnica de Cataluña, Barcelona

José Joaquín Parra Bañón. Escuela Técnica Superior de Arquitectura, Universidad de Sevilla

Víctor Pérez Escolano. Escuela Técnica Superior de Arquitectura, Universidad de Sevilla

Fernando Pérez Oyarzún. Escuela de Arquitectura y Diseño, Pontificia Universidad Católica, Santiago de Chile Judith Sheine. School of Architecture and Allied Arts, University of Oregon, Portland

Andrés Walliser Martínez. Global Design, New York University, Nueva York

\section{ISSN 2340-177X}

Depósito legal M-13872-2013

(c) de los textos, sus autores

(c) de las imágenes autorizadas

(c) Revista Constelaciones

๑) Escuela Politécnica Superior, Universidad CEU San Pablo

Universidad CEU San Pablo

Escuela Politécnica Superior

Urbanización Montepríncipe, $s / n$

Boadilla del Monte, 28668. Madrid (España)

constelaciones@eps.ceu.es

www.uspceu.es

Edición Edition

Fundación Universitaria San Pablo CEU

Madrid, España

Impresión Printing

VA Impresores

Impreso en España Printed in Spain

Distribución Distribution

CEU Ediciones

Los textos que componen Constelaciones se obtienen mediante convocatoria pública. Para que los trabajos recibidos entren en el proceso de selección de los artículos a publicar deben ser trabajos originales no publicados anteriormene, con una extensión recomendada de 3.000 palabras, título, resumen (un máximo de 150 palabras) y palabras clave (un mínimo de cuatro palabras), en español y en inglés. Tras haber cumplido estos requisitos (y los correspondientes incluidos en las normas editoriales de la revista, disponibles para consulta en formato digital desde el comienzo de la convocatoria), tiene lugar un proceso de revisión y evaluación de los artículos previa aceptación de los mismos para su publicación. Para acometer dicho proceso, y con el fin de asegurar la calidad de los contenidos, la Revista Constelaciones recurre a evaluadores externos a la institución editora y anónimos (cada artículo es evaluado por dos de ellos) encargados de someter a crítica los mismos. Todos los artículos de investigación publicados en esta revista han pasado por dicho proceso. La recepción de artículos se extendió hasta el 30 de Septiembre de 2013. Texts included in Constelaciones are obtained by public announcement. Only original papers that have not been previously published will be included in the process of selection of articles. They should not exceed 3.000 words and should include a title, an abstract (no more than 150 words) and keywords (a minimum of four words), in Spanish and English. After having fulfilled these requirements (and those included in magazine editorial standards, available for consultation from the beginning of the Call for Papers), occurs a process of review and evaluation of articles upon acceptance of them for publication. To undertake this process, and in order to ensure the quality of the contents, Constelaciones turns to external and anonymous evaluators to the institution (each article is evaluated by two of them) responsible for the critic. All the articles published in this journal have undergone this process. The deadline for reception was extended until September 30, 2013.

Todos los derechos reservados. Esta publicación no puede ser reproducida, ni en todo ni en parte, ni registrada, ni transmitida, ni almacenada en ningúna forma ni por ningún medio, sin la autorización previa y por escrito del equipo editorial. En este número se han utilizado algunas imágenes de las que no se ha podido identificar al propietario de los derechos. En estos casos hemos entendido que las imágenes son de libre uso. En caso de identificar alguna de estas imágenes como propia, por favor, póngase en contacto con la redacción de Constelaciones. Los criterios expuestos en los diversos artículos de la revista, son responsabilidad exclusiva de sus autores, y no reflejan necesariamente los que pueda tener el equipo editoral. El equipo editorial de la revista no se responsabiliza de devolver la información enviada a la redacción a no ser que se le solicite expresamente. All rights reserved. This publication cannot be reproduced, in whole or in part, nor registered, transmitted or stored in any form or by any means, without the written permission of the Editorial team, In this issue some images were used without knowing the owner of the rights. In these cases, we have understood that the images are free of use. In case you identify written permission of the Editorial team, In this issue some images were used without knowing the owner of the rights. In these cases, we have understood that the images are free of use. In case you identify
any of these images as your own, please, contact with the Editorial staff of Constelaciones. The opinions expressed in this issues's articles are entirely the responsibility of their authors and are not necessarily shared by the editors of this journal. The publisher don't take responsibility for returning submitted material which is not expressly requested. 


$$
11
$$




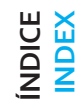

$\stackrel{n}{\sim}$

ร

5

$\curvearrowright$

๙ิ

$\stackrel{n}{=}$

$\bar{m}$
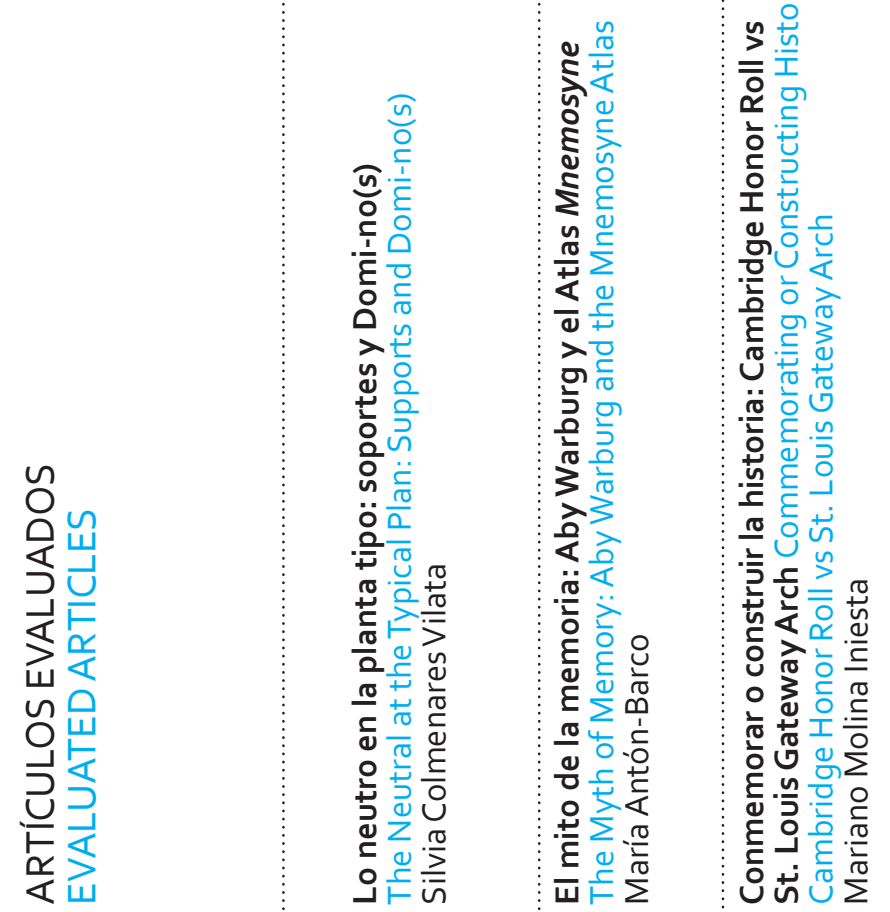

旁 을

‥

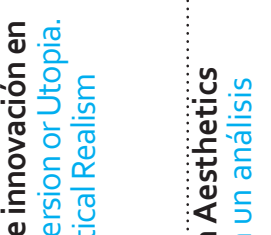

앙

胥苞

$\bar{\Psi}$

宛

일

능홍

区告

음 흠

응 흥

\%

든

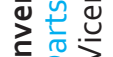

ข

음

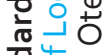

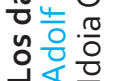

a व

은

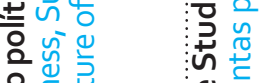

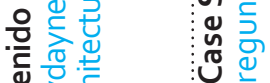

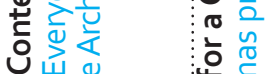

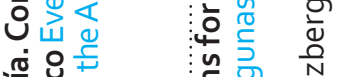

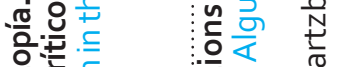

गे

गे० गे ये ज

:

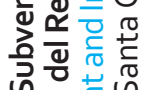

है

ज०

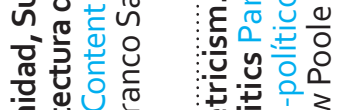

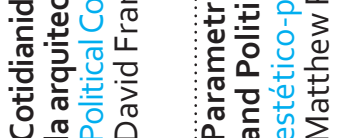

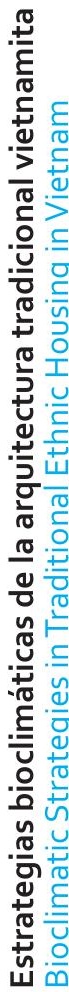

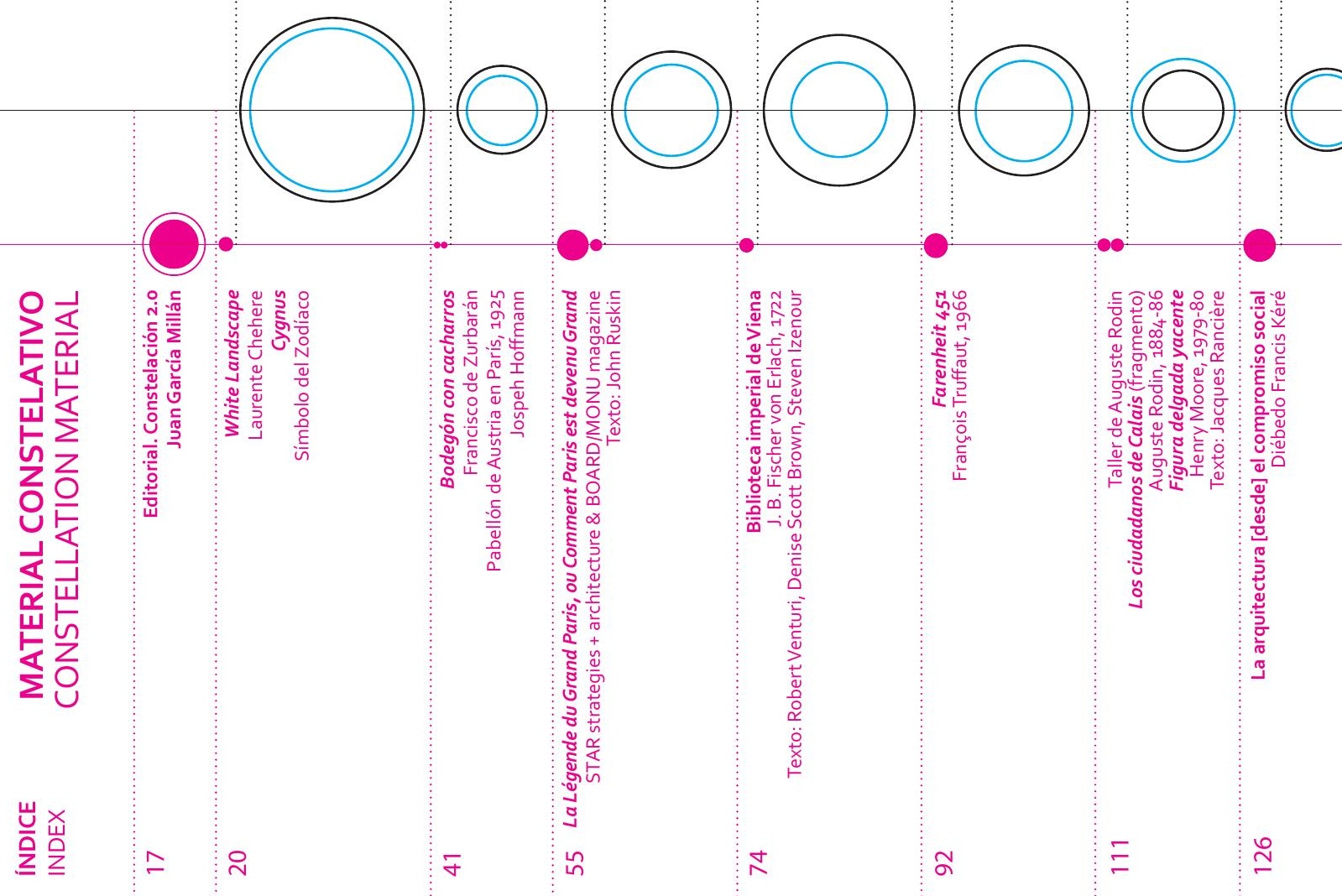

苍

० 


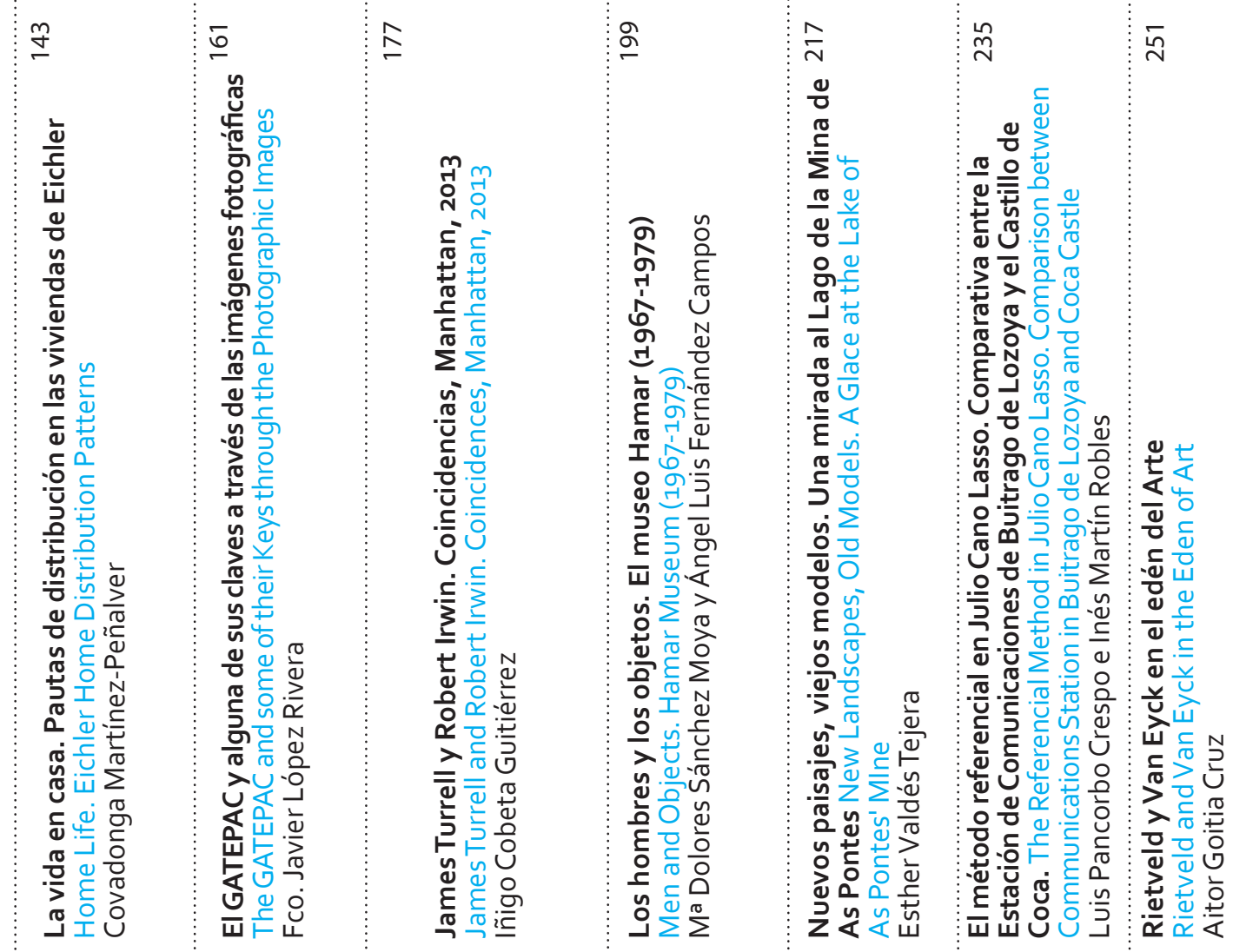
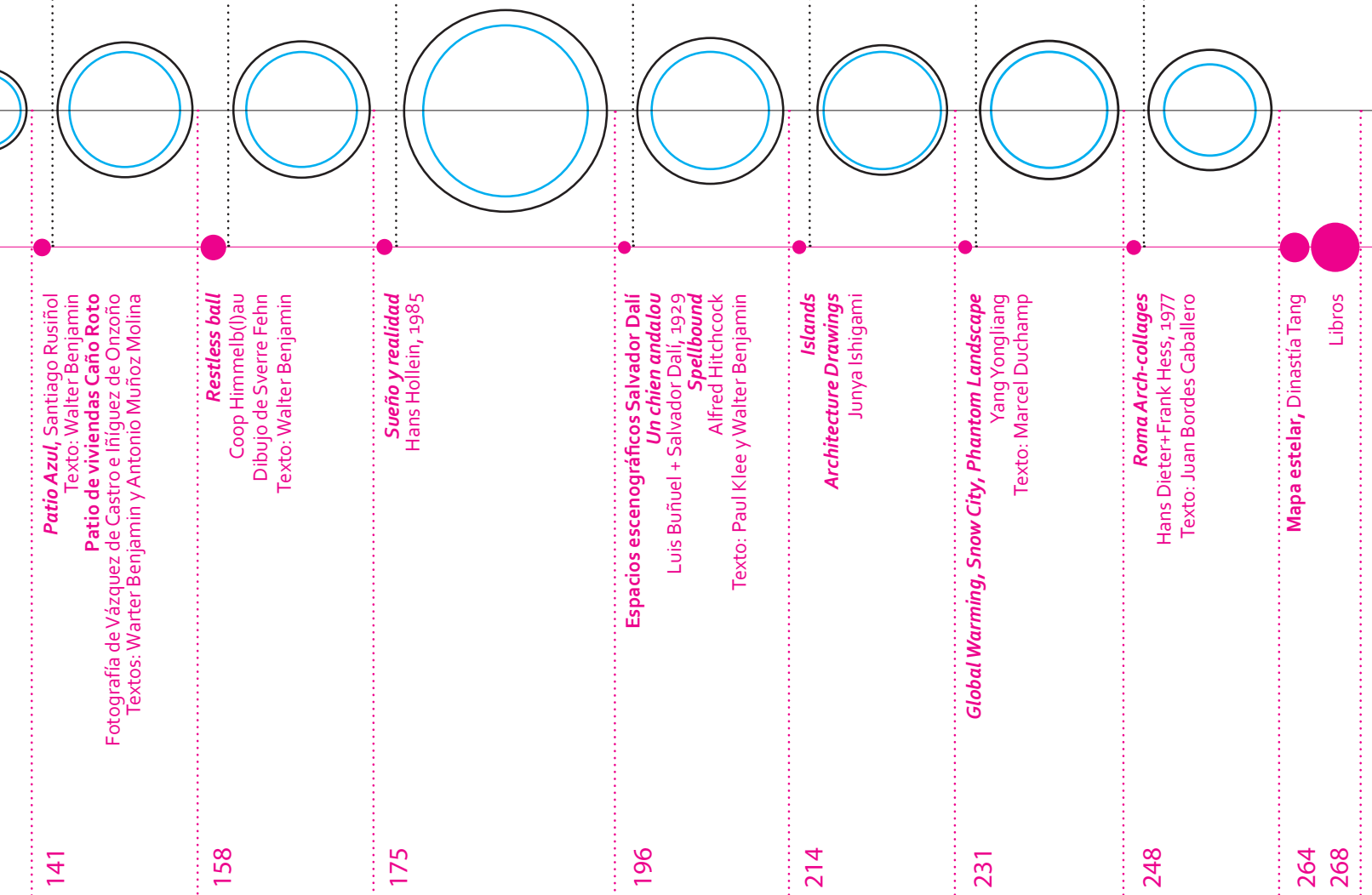


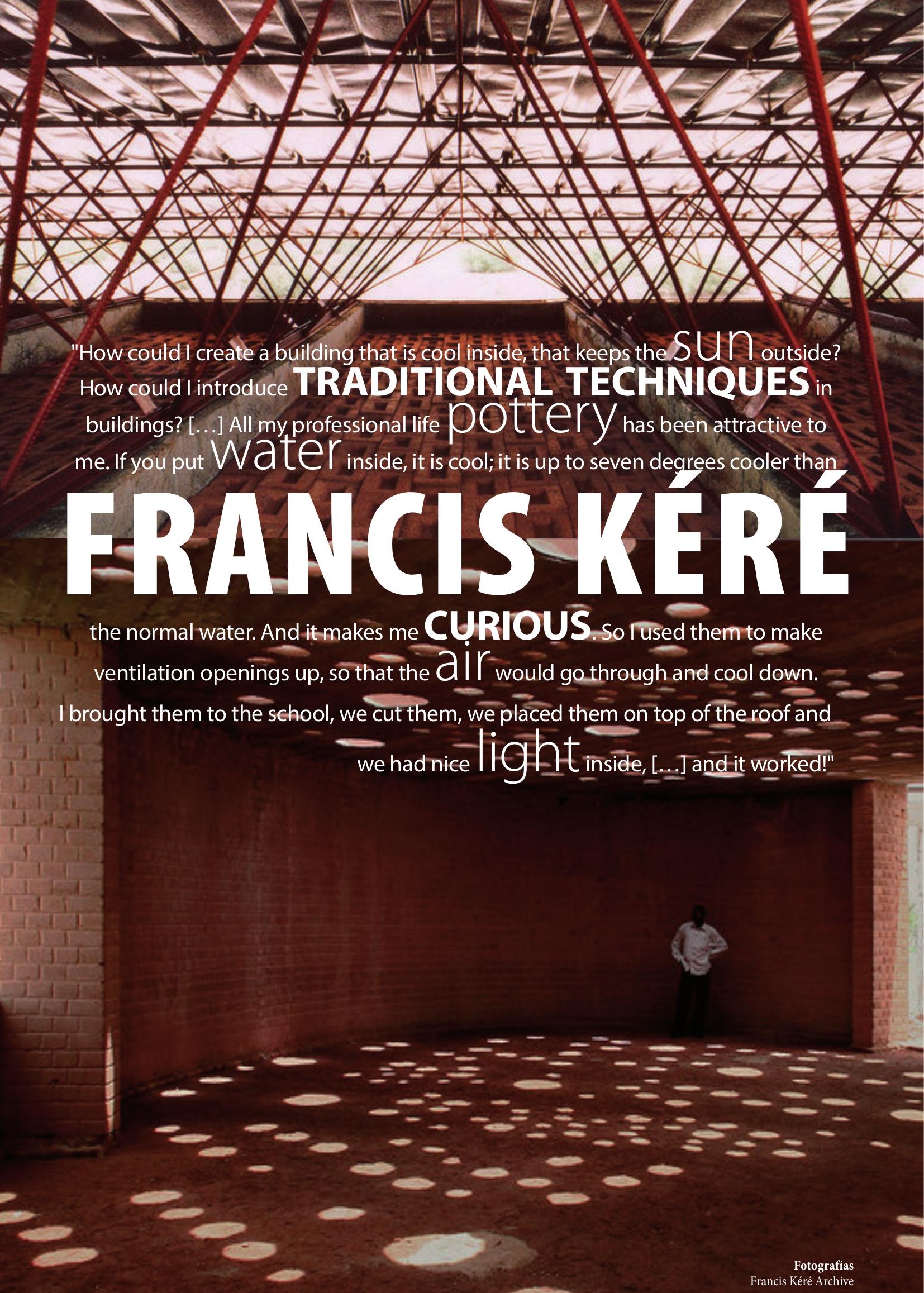




\title{
Estrategias bioclimáticas de la arquitectura tradicional étnica vietnamita Bioclimatic
} Strategies in Traditional Ethnic Housing in Vietnam

\author{
David Palomar Aguilar ${ }^{[1]}$, Consolación Ana Acha Román ${ }^{[2]}$ y Benito Lauret Aguirregabiria ${ }^{[2]}$ \\ ${ }^{[1]}$ Escuela de Arquitectura, Universidad Europea, Madrid \\ ${ }^{[2]}$ Escuela Técnica Superior de Arquitectura, Universidad Politécnica, Madrid. \\ Traducción Translation Rosa Montes, Elena Pascual
}

\section{Palabras clave Keywords}

Arquitectura bioclimática, Vietnam, étnica, tradicional, vivienda, Than Lâm Cham Bioclimatic architecture, Vietnam, ethnic, traditional, housing, Cham's Than Lâm

\section{Resumen}

La arquitectura tradicional es un referente útil en el planteamiento de estrategias pasivas de acondicionamiento higrotérmico y el empleo de los materiales. El presente artículo describe el funcionamiento bioclimático de cuatro tipologías de la arquitectura tradicional vietnamita de las etnias: É-De, Bahnar, Tay y Cham. La doble cubierta del Than Lâm Cham es uno de los casos más singulares de aislamiento frente a la radiación infrarroja. A pesar de sus diferencias formales, los ejemplos analizados coinciden en la protección solar, la elevación sobre el terreno y la ventilación natural como principales estrategias de acondicionamiento.

\section{Abstract}

Traditional architecture is a useful reference in the study of passive hygrothermal conditioning and the use of materials. This article describes the passive bioclimatic strategies of four Vietnamese ethnic traditional houses: É-De, Bahnar, Tay and Cham. The Cham's Than Lâm. Double roof is one of the most singular cases of insulation against infrared radiation.

Despite their formal differences, the analyzed examples coincide in sun shading, floor elevating and natural ventilation as the main conditioning strategies. 
La arquitectura de Vietnam es tremendamente heterogénea, fruto de una historia convulsa en la que conflictos y migraciones se han sumado a lo largo de siglos. Jemeres, chams, chinos, portugueses, japoneses, franceses, norteamericanos y soviéticos han dejado su impronta. A ellos se añaden un gran número de etnias minoritarias que de forma discreta han convivido en este territorio hasta la actualidad. Vietnam está habitada por 54 etnias distintas, siendo la Viet, de origen chino, la más numerosa y que da nombre al país. Es la arquitectura de algunos de estos grupos étnicos, adaptados a su entorno, la que se analiza en este artículo, desgranando las claves de su confort climático. La arquitectura colonial en contraposición, cuenta con grandes ventanales acristalados y gruesos muros herméticos más propios del clima continental europeo. $\mathrm{Su}$ adaptación local prolongó los aleros y extendió el uso de contraventanas. En la actualidad debería reflexionarse sobre cómo el modelo 'neocolonial' de rascacielos acristalado occidental se sigue exportando a todo el mundo, resolviendo con alta tecnología el concepto energéticamente ineficiente que es construir edificios-invernadero en climas cálidos.

Clima. Los niveles de radiación solar son altos debido a su proximidad al ecuador. En Vietnam se diferencian tres climas: norte, central y sur. (Fig. 1) Las montañas del interior a lo largo de su frontera oeste, condicionan a su vez las temperaturas en las zonas más altas. La zona norte, donde se encuentra la capital (Hanói), tiene un invierno suave con pocas precipitaciones y
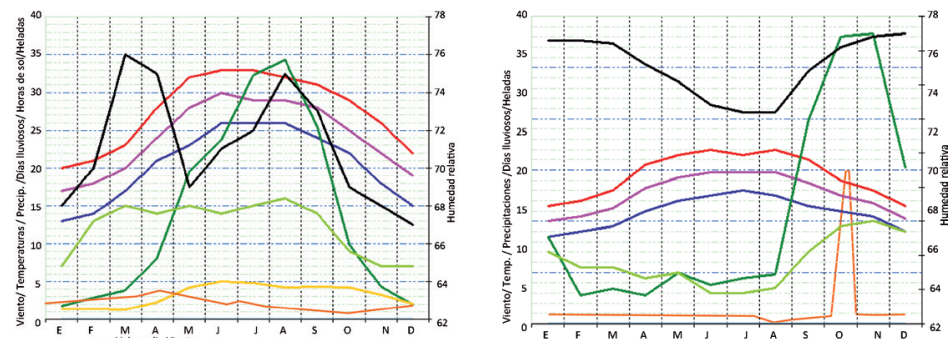
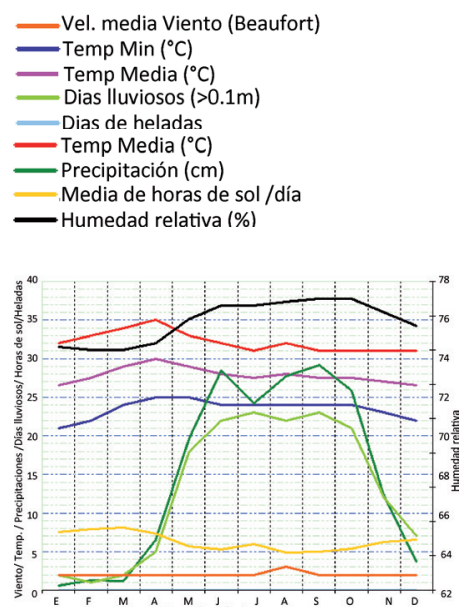

Fig. 1. Diagramas climáticos: Hanoi, Quang Tri, Ho Chi Minh, 2013.

Fuente: www.vietnam.climatemps.com

Vietnam's architecture is extremely heterogeneous, the result of a turbulent history in which conflict and migration has been added to over the centuries. Khmers, Chams, the Chinese, the Portuguese, the Japanese, the French, Americans and Soviets have left their mark. To them a large number of ethnic minorities, who have lived discretely in this territory up to the present, are added. Vietnam is inhabited by 54 different ethnic groups, being the Viet, of Chinese origin, the largest and that which names the country. It is the architecture of some of these ethnic groups, adapted to their environment, which is analysed in this article, reeling off the keys to its climatic comfort.

Colonial architecture, in contrast, has large glass windows and airtight thick walls more proper to the European continental climate. Local adaptation extended eaves and widespread the use of shutters. Today we should reflect on how the Neocolonial western model of glass skyscrapers is still being exported worldwide, working out with high technology, the energy inefficient concept that building conservatory buildings in hot climates is.

Climate. Sun radiation levels are high due to its proximity to the equator. There are three different climates in Vietnam: North, Central and South. The interior mountains along its western border influence the temperatures in the higher areas. The northern area, where the capital, Hanoi, is located, has a mild winter with little rainfall and temperatures rarely drop below ten degrees, except in the mountains. The rest of the year is warm and humid. Annual hours of sunshine range between 1.400 and 2.100 according to the provinces. (1) 
las temperaturas rara vez descienden de los diez grados, salvo en las montañas. El resto del año es cálido y húmedo. Las horas de sol anuales oscilan entre 1.400 y 2.100 , según las provincias. (1)

La zona central (Quang Tri) posee un clima tropical con una estación seca y otra húmeda, con monzones en octubre. La proximidad del mar hace que las temperaturas varíen muy poco, por lo que no es necesario protegerse del frío, aunque sí de la lluvia en forma de tormentas tropicales y tifones.

El sur (Ho Chi Minh/Saigón) presenta sólo dos estaciones: la húmeda, con dos temporadas de monzones y la seca, en un invierno igualmente cálido. La temperatura, humedad y radiación solar son muy altas todo el año. En las provincias al sur de Hue se registran de 1.900 a 2.900 horas de sol al año. (2)

Casa É-Dê. Tradicionalmente la etnia É-Dê es una sociedad matriarcal. Se concentran en las provincias de Lac Dac, Gia Lai meridional, partes occidentales de Khanh Hoa y de Phu Yen. (3) (Fig. 2) Hasta mediados del siglo xx, varias familias vivían juntas en este tipo de vivienda alargada, (Fig. 3) que se amplía por agregación de nuevos miembros al núcleo familiar y que pueden alcanzar los 85 metros de longitud. Todas las uniones, incluidas las estructurales, se realizan mediante atados y cajeados, prescindiendo de herrajes.
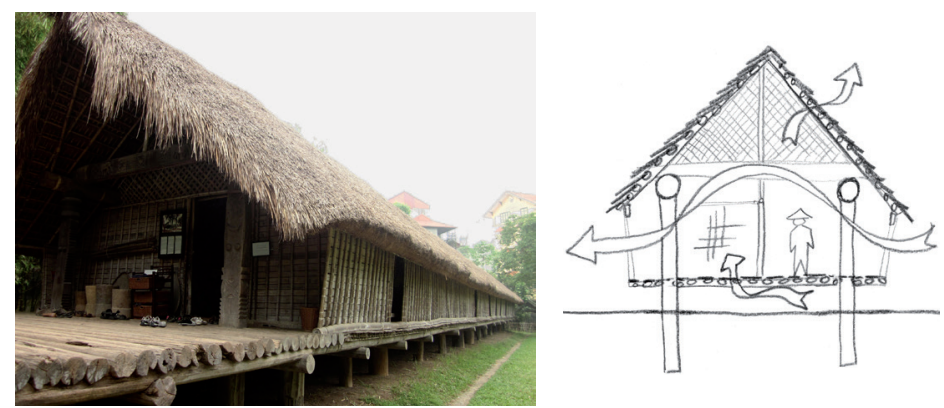

Fig. 2. Población É-Dê. Lemoine (3)

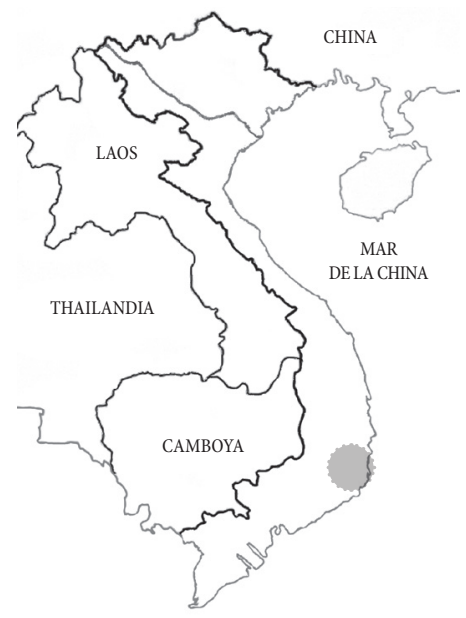

Fig. 3. Casa É-Dê. Fotografía del autor, 2012.

Fig. 4. Ventilación Casa É-Dê. Dibujo del autor, 2013.

The Central Zone, Quang Tri, has a tropical climate with a dry season and a wet one with monsoon in October. The proximity to the sea makes the temperatures vary very little, so protection from the cold is not necessary, although it is from the rain which comes in the form of tropical storms and typhoons. The South, Ho Chi Minh and Saigon, has only two seasons, a wet one with two monsoon seasons and a dry one, also with a warm winter. The temperature, humidity and solar radiation are very high throughout the year. In the provinces South of Hue 1.900-2.900 hours of sunshine are recorded annually. (2)

É-Dê housing. Traditionally the É-Dê ethnic group is a matriarchal society. They are concentrated in the provinces of Dac Lac, Gia Lai southern, western parts of Khanh Hoa and Phu Yen. (3) (Fig. 2) Until the mid-twentieth century, several families lived together in this type of elongated housing, (Fig. 3) which is enlarged as new members are added to the family unit, being able to reach 85 meters in length. All joints, including structural, are made by bound and mortises, without ironwork.

The most important hygrothermal conditioning strategies are ventilation and sun protection. The walls based on slats with open joints are highly permeable to air. The windows, made of panels of cane strips or braided bamboo, are practicable, allowing lighting and ventilation. The same happens in the headers which are reduced to a lattice at their upper end. The floor 
Las estrategias de acondicionamiento higrotérmico más destacadas son la ventilación y protección solar. Las paredes a base de tablillas con juntas abiertas son muy permeables al aire. Las ventanas de paneles de tiras de caña o bambú trenzadas son practicables, permitiendo la iluminación y ventilación. Igualmente ocurre en los testeros que se reducen a una celosía en su extremo superior. El suelo de vigas de madera sobre postes hincados, se remata con una estera muy resistente de tiras de bambú cosidas. Al elevarse sobre el terreno, evita la humedad y permite la entrada de aire desde el espacio sombreado que hay debajo.

Las paredes bajas, minimizan su exposición al sol y la lluvia, quedando además protegidas por un pequeño alero. En algunos casos, las hojas de palmera de la cubierta no se recortan en el vierteaguas, descolgando verticalmente y ofreciendo una protección solar adicional. Las habitaciones interiores se compartimentan mediante paneles trenzados como las ventanas, pero de una altura muy inferior a la del tejado, permitiendo que el aire fluya sobre ellos. (Fig. 4)

Casa comunal Bahnar. Los Bahnar son una de las minorías étnicas que viven en la provincia Kon Tum, en las montañas centrales del país y en diferentes partes de las provincias de Binh Dinh y de Phu Yen. (4) (Fig. 5) La casa comunal (Fig. 6) era el edificio más importante de las aldeas Bahnar, en la que los hombres se reunían para la celebración de rituales y la planificación de la defensa o la guerra. Aunque existen otros ejemplos de esta tipología, la mayoría se encuentran actualmente alterados por reparaciones. En las vigas del techo se han sustituido los antiguos rollizos por secciones escuadradas, los suelos de bambú por tablones de madera, las escaleras de troncos labrados por nuevas de cemento e incluso los tradicionales techos de paja pueden verse sustituidos por chapas de acero onduladas.

Los materiales originales de este tipo de construcción son: madera, bambú, cañas y paja. El acceso se realiza a través de escalas labradas en gruesos troncos. En el edificio de la imagen, los postes de cimentación se hincan en el terreno, miden seis metros de longitud, alcanzan los 60 centímetros de diámetro y elevan la plataforma de madera tres metros sobre rasante. Las

made of wooden beams on driven poles, is topped with a hard mat of sewn bamboo strips. By rising from the ground, humidity is avoided and it allows the entry of air from the shaded space below.

The low walls, minimize their exposure to sun and rain, and are also protected by a small eave. In some cases the palm leaves of the cover are not trimmed in the gutter, hanging and offering additional sun protection. The inner rooms are partitioned by braided panels like the windows, but much lower than the roof height, allowing air to flow over them. (Fig. 4)

Bahnar communal housing. The Bahnar are one of the ethnic minorities living in the Kon Tum province, in the central highlands of the country and in different parts of the provinces of Binh Dinh and Phu Yen. (4)(Fig. 5)

The communal house (Fig. 6) was the most important building of the Bahnar villages where men gathered to celebrate rituals and for defense or war planning. Although there are other examples of this typology, most are currently altered by repairs. In the rafters, the old logs have been replaced by squared sections, bamboo flooring for wooden planks, the stairs made of hewn logs for new ones made of cement and even traditional thatched roofs have be replaced by corrugated steel sheets. 
vigas del suelo miden de catorce a quince metros de largo, y las del techo trece metros, alcanzando la cumbrera los diecinueve metros de altura. En la casa comunal original de Mo nai, otro pueblo situado en la misma provincia de Kontum, la madera empleada fue de Trắc, una madera dura del género de la Dalberigia; se conservan los postes de cimentación originales de 1975. (5)

$\mathrm{Al}$ margen de las implicaciones religiosas y representativas, que condicionan en gran medida esta tipología, cabe señalar desde el punto de vista higrotérmico, la gran cubierta apuntada que favorece la ventilación, actuando como una chimenea en la que el aire caliente asciende filtrándose a través de la amplia superficie del techo de paja. Las paredes bajas minimizan su exposición al sol y se transforman en celosías muy abiertas en su encuentro con la cubierta, permitiendo la ventilación, pero protegidas de la entrada de lluvia o radiación solar directa. Las juntas abiertas, tanto en paredes como suelo, permiten la renovación del aire y gracias a la elevación sobre pilotes, no se ve afectada por la humedad de suelo. (Fig. 7)
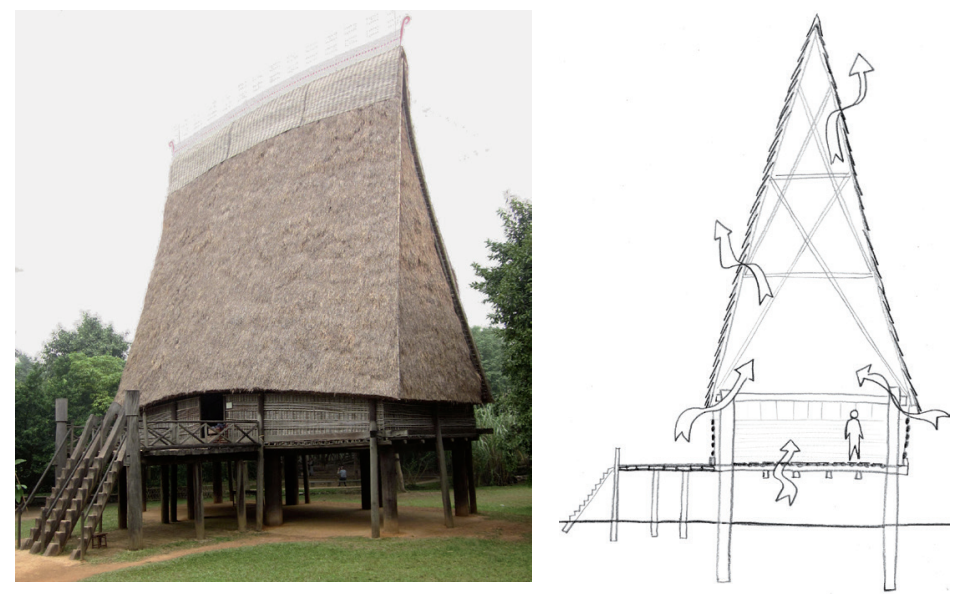

Fig. 5. Población Bahnar. (3)
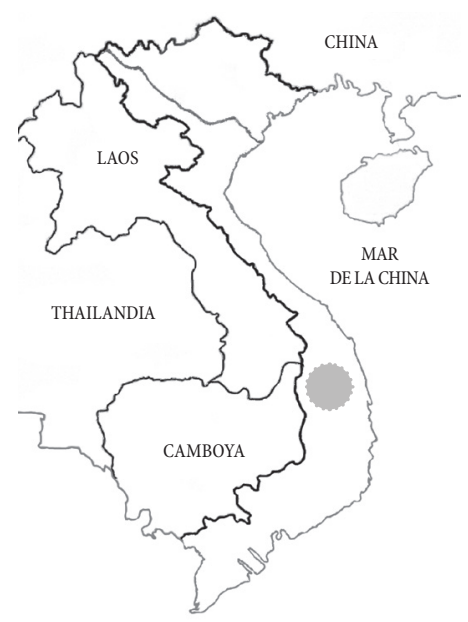

Fig. 6. Casa Comunal Bahnar. Fotografía del autor, 2012. Fig. 7. Ventilación Casa Bahnar. Dibujo del autor, 2013.

The original materials of this kind of construction are wood, bamboo, reeds and straw. Access takes place through ladders carved in thick trunks. In the building in the image, foundation poles are driven into the ground, measuring six meters in length, reaching 60 centimeters in diameter and raising the wooden platform three meters above ground. The floor beams measure fourteen to fifteen meters long, and thirteen meters the ones in the roof, reaching the ridge height of nineteen meters.

In the original Mo nai Communal House, another village in the same province of Kontum, Trac wood was used, a hardwood from the genre of Dalberigia. It still keeps the original 1975 foundation poles. (5) Besides the religious and representative implications which greatly condition this typology, it is noted from the hygrothermal point of view, that the great targeted cover favours ventilation, acting as a chimney in which warm air rises through the filtering wide thatch surface.

The low walls minimize sun exposure and become very open lattices in their encounter with the cover, allowing ventilation but protected from the entry of rain or direct sunlight. Open joints, both in walls and floor allow air exchange and thanks to the elevation on piles it is not affected by soil humidity. (Fig. 9) The space under the house is in shade and acts as a cooling surface. The temperature difference between this space and the air under the cover creates an updraft that promotes passive ventilation. 
El espacio bajo la casa está en sombra y actúa como plano radiante refrescante. La diferencia de temperatura entre este espacio y el aire que existe bajo cubierta crea una corriente ascendente que favorece la ventilación pasiva.

Casa Tay. Los Tay viven a lo largo de los valles y en las faldas de las montañas en Cao Bang, Lang Son, Bac Can, Thai Nguyen y las provincias de Quang Ninh, y en algunas regiones de la provincia de la Bac Giang. (6) (Fig. 8)

Esta vivienda (Fig. 9) fue construida en 1967, en la comuna Binh Yen de Tham Roc, en la provincia Nguyen, al norte del país. Debido a la guerra con Estados Unidos (1965-1973), fueron en su mayoría mujeres las que trabajaron en su construcción. La vivienda-palafito tiene tres estancias principales y dos ampliaciones. La adoración de los antepasados es uno de los ritos religiosos de los Tay. El altar para los antepasados se coloca en una localización central de la casa. (Fig. 10) La ubicación y orientación, así como el día del comienzo de la construcción o de la cubrición del techo están determinados por las creencias en la fortuna.

La cocina es un cajón de tierra sobre el forjado de madera, sobre el que se enciende un fuego. En invierno se mantiene encendido para caldear el
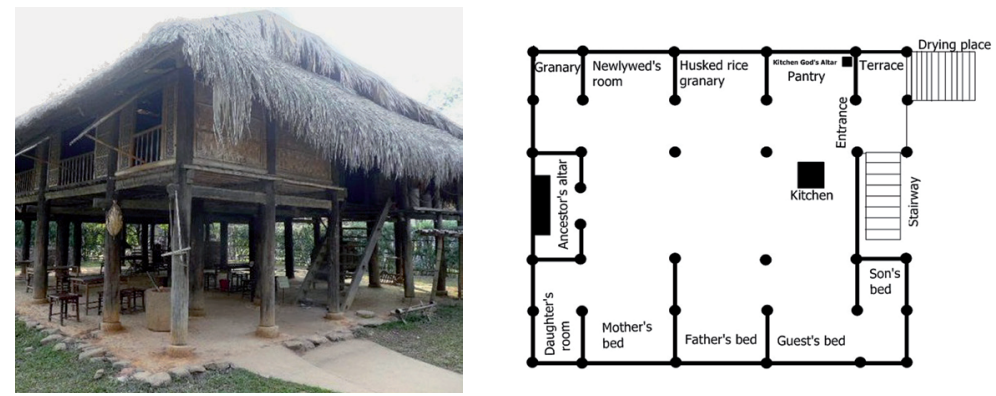

Fig. 9. Casa Tay. Thaodp, Mit: Tay's traditional stilt house, 2013.

Fig. 10. Planta Casa Tay. Thaodp, Mit: Tay's traditional stilt house, 2013.

Tay housing. The Tay live along the valleys and on the slopes of mountains in Cao Bang, Lang Son, Bac Can, Thai Nguyen and Quang Ninh provinces, and in some regions of the province of Bac Giang. (6) (Fig. 8)

This house (Fig. 9) was built in 1967, in the commune of Binh Yen Tham Roc Nguyen province, north of the country. Because of the war with the United States (1965-1973), mostly women worked in construction. The stilt house has three main rooms and two extensions. The worship of ancestors is one of the religious rites of the Tay. The ancestor altar is placed in a central location of the house. (Fig. 10) The location and orientation as well as the starting date of the construction or the roof covering are determined by beliefs in fortune.

The kitchen is an earth box on the wooden slab in which a fire is lit. In winter it stays on to heat up the place. When the weather does not allow appliances to dry outside on a platform next to the terrace, a rack of bamboo logs is placed above the fire. The elevated structure protects from floods. With the elevation the speed of the air increases (at ground level it is almost zero), improving ventilation. (Figs. 11, 12)

The upper part of the central uprights is decorated with lots of flowers engraved on the wood. The walls are formed by a web of bamboo strips that make up the traditional style panels. The roof has over 6.000 palm leaves tied with fibres. 
ambiente. Sobre él se dispone un estante de rollizos de bambú que permiten secar los enseres cuando el tiempo no permite hacerlo al exterior en una plataforma situada junto a la terraza.

La estructura de palafito protege de las eventuales inundaciones. Con la elevación también aumenta la velocidad del aire (que a nivel del suelo es casi nula), mejorando la ventilación. (Figs. 11, 12)

La parte superior de los pies derechos centrales están decorados con flores de loto grabadas en la madera. Las paredes están formadas por una urdimbre de tiras de bambú que conforman paneles al estilo tradicional. El techo cuenta con más de 6.000 hojas de palmera atadas con fibras, empleando cuchillos y hachas para su construcción. Cuenta con cuatro faldones; los dos más grandes se repuntan, creando dos aguilones y los menores actúan de embudo para las brisas favoreciendo la ventilación por la cubierta. (7)

La imagen (Fig. 13) corresponde a la parte inferior del forjado sanitario. En ella, podemos observar el detalle de sus cinco niveles estructurales: pies derechos sobre zócalos de piedra que evitan el contacto de los mismos con la humedad del terreno, vigas de atado y vigas de carga sobre las que a su vez se atan, literalmente, tres capas de bambú conformando un suelo flexible
Fig. 8. Población Tay. (3)

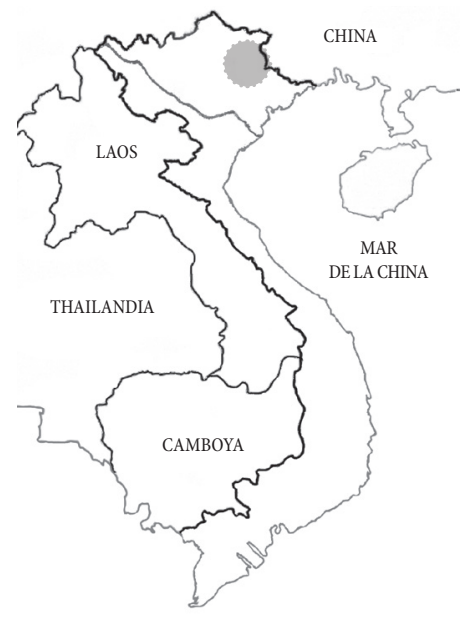

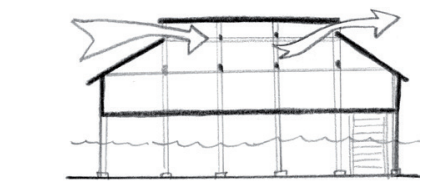

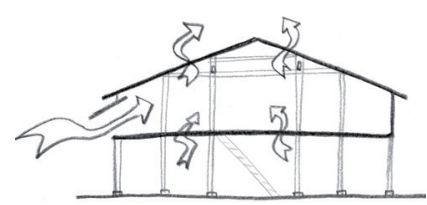

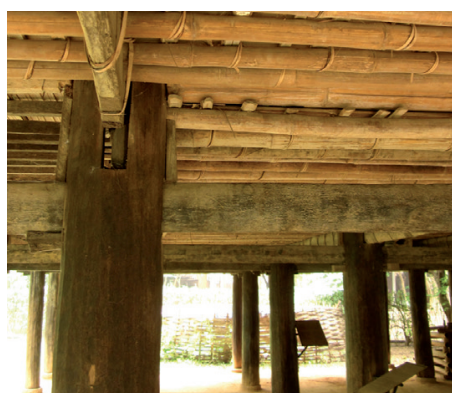

Figs. 11, 12. Ventilación pasiva Casa Tay. Dibujo del autor.

Fig. 13. Forjado Casa Tay. Fotografía del autor, 2012

Knives and axes are used for its construction. It has four pitches, the two largest rebound, that create two gables and the smaller ones that act as a funnel for the breeze, favouring ventilation through the cover. (7)

This picture (Fig. 13) corresponds to the bottom of the 'sanitary slab'. Here we can observe the detail of its five structural levels. Studs on stone plinths that avoid contact thereof with soil moisture, tie beams and load beams on which three bamboo layers are tied, forming a flexible yet extremely resistant floor and what is more important, allowing air filtration from a shaded area as has been analysed in the previous example.

Cham housing. The Cham ethnic group comes from the ancient kingdom of Champa, (875-1832), when the Vietnamese Emperor Minh Mang annexed their last territories in the centre-south of modern Vietnam. Today Cham populations are concentrated in the provinces of Ninh Thuan and Binh Thuan. Before, they also lived in An Giang, Tay Ninh, Dong Nai and Ho Chi Minh. (8) The Cham belong to the Malay-Polynesian ethnic group; (9) formerly Hindus and Buddhists, it is a matriarchal society. They consitute a Muslim minority of about one hundred thousand inhabitants, versus the major ethnic group (the Viet-Kinh), with 65 million inhabitants in the country. (Fig. 14) 
pero tremendamente resistente y lo que es más importante, permitiendo la filtración de aire desde una zona sombreada como se ha analizado en el ejemplo anterior.

Vivienda Cham. La etnia Cham proviene del antiguo reino de Champa, entre el año 875 hasta 1832, cuando el emperador vietnamita Minh Mạng se anexionó sus últimos territorios en el centro-sur del actual Vietnam. Hoy en día las poblaciones Cham están concentradas en las provincias de Ninh Thuan y Binh Thuan. Antes, también vivieron en An Giang, Tay Ninh, Dong Nai, y en la ciudad de Ho Chi Minh. (8) Los Cham Pertenecen al grupo de etnias malayo-polinesias; (9) antiguamente hinduistas y budista; se trata de una sociedad matriarcal que constituye una minoría musulmana de alrededor de cien mil habitantes (frente a la etnia Viet/Kinh, mayoritaria en el país, con unos 65 millones). (Fig. 14)

Las características que definen las viviendas Cham son su agrupación ordenada rodeadas de jardines rematados por un muro perimetral exterior. Cada hogar se compone de varios edificios con usos concretos. Las orientaciones habituales son sur y sur-oeste captando los vientos predominantes del clima sureño. (10) El Than Lâm, es uno de los edificios-estancia más importantes de una vivienda Cham. Alberga el dormitorio del propietario, así como los enseres más valiosos y en su construcción, se emplean habitualmente maderas de gran valor. El que aparece en las fotografías (Fig. 15) tiene más de un siglo de antigüedad y proviene de Truong Tho en la provincia de Ninh Thuân.

Generalmente cuentan con una única planta baja apenas elevada 0,3 metros sobre el terreno. La cimentación consiste en dados de piedra sobre los que se levanta un suelo de tablones de madera o trenzado de bambú. Las particiones interiores son de madera, con puertas que dan acceso desde el porche a las estancias interiores, mientras que al exterior se diferencian claramente dos cerramientos: un muro ciego de ladrillo o tapial y un porche sombreado por la cubierta con una celosía de tablones escuadrados verticales. En este porche, el durmiente del suelo, así como la carrera están labrados en toda su longitud para alojar los tablones verticales, que se aseguran con un pasador

The defining feature of the Cham dwellings is its ordered grouping surrounded by gardens, enclosed by an outer perimeter wall. Each household consists of several buildings with concrete uses. The usual orientations are south and south-west capturing the prevailing winds of the southern climate. (10) The Than Lâm, is one of the most important stay-buildings of a Cham dwelling. It houses the owner's bedroom as well as the most valuable goods and in its construction valuable woods are usually used. The one in the photographs (Figs. 14, 15) is more than a century old and comes from Truong, the province of Ninh Thuan.

Generally they have only a single ground floor elevated 0.3 meters above the ground. The foundation is made by cubes of stone on which a wooden plank or braided bamboo floor rises. The inner partitions are made of wood with doors leading from the porch to the interior spaces, while outside two enclosures are clearly distinguished: a blind mud or brick wall and a porch shaded by the cover, with a lattice of squared vertical planks. In this porch, the ground sleeper and the race are carved over their entire length to accommodate the vertical planks which are secured with a pin at the upper end, allowing great flexibility in the configuration of accesses and openings.

The most peculiar element of Than Lâm is the double cover. (Fig. 16) The upper one, agâk ralang, made of straw or as in this case, flat ceramic tiles on battens, rises 0.5 meters above another of clay and straw with a wide open perimeter. 
en el extremo superior, permitiendo así una gran flexibilidad en la configuración de accesos y aberturas.

El elemento más singular del Than Lâm es la doble cubierta. (Fig. 16) La superior, (agâk ralang) de paja o como en este caso, de teja cerámica plana sobre rastreles, se eleva 0,5 metrros sobre otra de barro y paja con su perímetro completamente abierto.

En un edificio de una sola planta, el espacio vividero queda en contacto con la cubierta. Bajo una intensa radiación solar, esta cubierta cerámica actúa a su vez como un cuerpo radiante enviando calor en dirección perpendicular a su superficie; de no interponer un elemento con masa suficiente, la radiación infrarroja alcanzaría la zona vividera, causando una pérdida de confort. La capa de barro de 0,1 metros de espesor crea un efecto pantalla y el aire que circula entre ambas cubiertas evita su sobrecalentamiento.

Conclusiones. Las construcciones analizadas presentan una gran adaptación al clima de las zonas en que se ubican, empleando recursos locales limitados. Aún con variaciones morfológicas y constructivas, coinciden en la ventilación y protección solar como medidas fundamentales de acondicio-
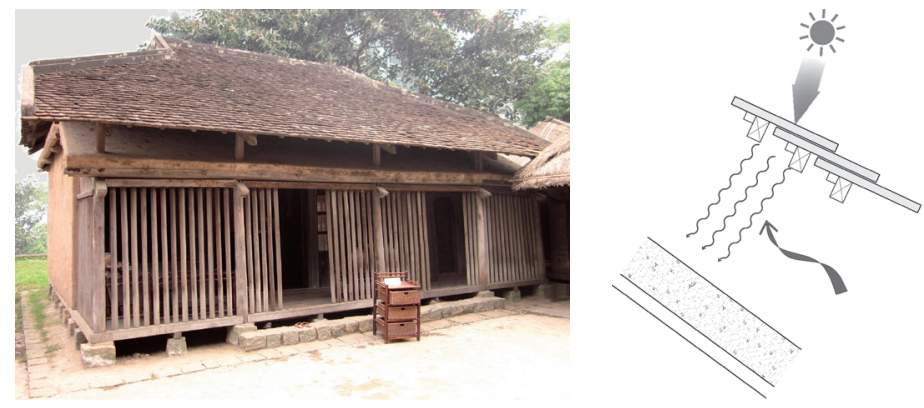

Fig. 15. Cham Than Lâm. Fotografía del autor, 2012.

Fig. 16. Detalle de cubierta ventilada de un agâk ralang de teja cerámica. Dibujo del autor, 2012.

In a one-story building, the livable space is in contact with the cover. Under intense solar radiation, this ceramic coating acts as a radiant body sending heat perpendicularly to its surface. If an element with sufficient mass was not interposed, infrared radiation would reach the living area, causing a loss in comfort. The clay layer 0.1 meters thick acts as a screen and the air circulating between both decks prevents overheating.

Conclusions. The constructions analysed are greatly adapted to the climate of the areas where they are located, using limited local resources. Even with morphological and structural changes they coincide in ventilation and sun protection as fundamental conditioning measures. The threat of severe storms results in single storey buildings, sloping roofs and the absence of chimneys as they could be toppled by the wind. Interior lighting levels are low, since solar shading is paramount in the opening of voids. (Fig. 17)
Fig. 14. Población Cham. (3)

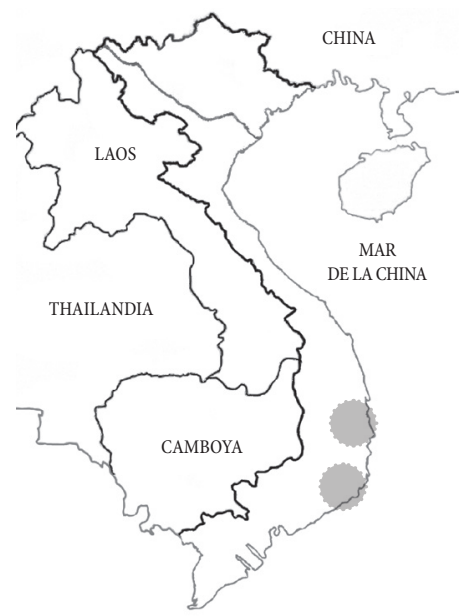


(Unit: kWh/m2/day)

\begin{tabular}{|l|c|c|c|c|c|c|c|c|c|c|c|c|c|}
\hline Province & $\mathbf{1}$ & $\mathbf{2}$ & $\mathbf{3}$ & $\mathbf{4}$ & $\mathbf{5}$ & $\mathbf{6}$ & $\mathbf{7}$ & $\mathbf{8}$ & $\mathbf{9}$ & $\mathbf{1 0}$ & $\mathbf{1 1}$ & $\mathbf{1 2}$ & Average \\
\hline Ha Giang & $\mathbf{1 . 2 4}$ & $\mathbf{2 . 6 6}$ & 2.85 & 3.91 & 4.61 & 4.22 & 4.46 & $\mathbf{4 . 5 4}$ & $\mathbf{4 . 4 9}$ & 3.34 & 2.83 & 2.25 & 3.45 \\
\hline Lao Cai & 2.37 & 2.77 & 3.42 & 4.29 & 5.01 & 4.61 & 4.60 & 4.57 & 4.39 & 3.45 & 2.82 & 2.32 & 3.72 \\
\hline Yen Bai & 2.16 & 2.58 & 3.13 & 4.59 & 4.44 & 4.68 & 4.68 & 4.59 & 3.84 & 3.05 & 2.19 & 2.49 & 3.54 \\
\hline Tuyen Quang & 2.37 & 2.39 & 2.70 & 3.40 & 5.00 & 4.25 & 4.97 & 4.80 & 4.70 & 3.91 & 3.11 & 2.52 & 3.69 \\
\hline Cao Bang & 2.25 & 2.45 & 3.04 & 4.07 & 5.42 & 5.35 & 5.29 & 5.85 & 5.19 & 4.16 & 3.22 & 2.77 & 4.15 \\
\hline Phu Tho & 2.42 & 2.45 & 2.67 & 3.60 & 5.24 & 4.85 & 5.21 & 4.79 & 4.82 & 4.20 & 3.35 & 2.77 & 3.87 \\
\hline Lai Chau & 3.29 & 3.83 & 3.58 & 5.43 & 5.32 & 4.48 & 4.54 & 4.73 & 4.81 & 4.12 & 3.46 & 3.12 & 4.12 \\
\hline Hoa Binh & 2.62 & 2.66 & 2.94 & 3.81 & 5.00 & 4.53 & 4.86 & 4.56 & 4.36 & 4.04 & 3.21 & 2.73 & 3.78 \\
\hline Hanoi & 2.44 & 2.40 & 2.53 & 3.46 & 5.23 & 5.31 & 5.59 & 5.10 & 4.79 & 4.18 & 3.45 & 2.97 & 4.08 \\
\hline Danang & 3.07 & 3.27 & 4.55 & 5.09 & 5.27 & 5.81 & 5.77 & 5.42 & 4.91 & 3.52 & 2.89 & 3.07 & 4.43 \\
\hline Binh Dinh & 3.16 & 4.06 & 4.99 & 5.93 & 5.93 & 5.76 & 5.55 & 5.80 & 5.35 & 4.07 & 3.02 & 2.80 & 4.70 \\
\hline Gia Lai & 4.28 & 5.15 & 5.51 & 5.66 & 5.51 & 4.96 & 4.71 & 4.57 & 4.48 & 4.45 & 3.84 & 3.80 & 4.79 \\
\hline Kon Tum & 4.10 & 4.98 & 5.53 & 5.74 & 5.32 & 4.59 & 4.26 & 4.45 & 4.1 & 4.55 & 3.85 & 3.67 & 4.61 \\
\hline Dak Lak & 4.07 & 4.82 & 5.06 & 5.23 & 4.73 & 4.45 & 4.24 & 4.21 & 3.97 & 3.91 & 3.61 & 3.54 & 4.32 \\
\hline Quang Ngai & 2.86 & 3.78 & 4.68 & 5.68 & 5.87 & 5.83 & 5.74 & 5.75 & 5.33 & 3.99 & 2,88 & 2.71 & 4.60 \\
\hline Nha Trang & 4.66 & 5.29 & 5.69 & 5.91 & 5.90 & 5.66 & 5.66 & 5.51 & 4.92 & 4.42 & 4.04 & 4.15 & 5.15 \\
\hline Ho Chi Minh city & 4.65 & 5.19 & 5.43 & 5.45 & 4.79 & $4 / 67$ & 4.34 & 4.78 & 4.42 & 4.40 & 4.31 & 4.28 & 4.72 \\
\hline
\end{tabular}

Fig. 17. Tabla de radiación solar por provincias. New Energy Sources Master Plan, 2001.

namiento. La amenaza de fuertes tormentas da lugar a edificios de una sola planta, cubiertas inclinadas y ausencia de chimeneas que podrían ser derribadas por el viento. Los niveles de iluminación interior son bajos, primando la protección solar en la apertura de huecos. (Fig. 17)

\section{NOTAS}

1. WAIBEL, Michael (ed.). Climate Change and Sustainable

Urban Development in Vietnam. Hanoi, 2010.

2. Ibídem.

3. LEMOINE, Jacques; KID-ARN, Kittima; BOODPHETCHARAT, Thanit; SAENMI, Sakda; TILLMAN, Timmi. 'Map of ethnics groups in Vietnam'. IKAP Network for capacity Building in MMSEA. Chiang Mai, 2005.

4. Ibídem.

5. SUZUKI, Haruka. “'Ironwood' utilization and its changes in Vietnam and Indonesia”. 2005.

6. LEMOINE, J.; KID-ARN, K.; et al. Opus cit.

7. NGUYEN, Anh-Tuan; TRAN, Quoc-Bao; TRAN, Duc-Quang; REITER, Sigrid. 'Climate responsive design strategies of vernacular housing in Vietnam'. Building \& Environment. n. 46, 2011. 8. LEMOINE, J.; KID-ARN, K.; et al. Opus cit.

9. Perry-Castañeda Library Map Collection. Universidad de Austin, Texas

10. LEMOINE, J.; KID-ARN, K.; BOODPHETCHARAT, T.; SAENMI, S.; TILLMAN, T. Opus cit.

\section{REFERENCIAS}

CHU, Q.T.; TRUC, K. Dân Gian Truyện Thông Việt Năm. (Traditional Popular Architecture in Vietnam). Hanoi: Fine Arts Publisher, 2004. HOANG, H.A. Cac Loai Nha Truyen Thong: Nha Ruong Classification Traditional Houses. Ruong" house. Guide to Restore Traditional House (Hue heritage house, 2003). Hue: Thuan Hoa Publisher, 2003. pp. 19-29

NGO, H.Q. Tim Hieu Lich Su Kien Truc Viet Nam: Research of Vietnam Architectural History. Hanoi: Construction Publisher, 2000. PHUONG, Ly; BIRKELAND, Janis; DEMIRBILEK, Nur. 'Applying environmentally responsive characteristics of vernacular architecture to sustainable housing in Vietnam' in Sustainable Architecture \& Urban Development. Amman, Jordania: CSAAR Press, 2010.

\section{NOTES}

1. WAIBEL, Michael (ed.). Climate Change and Sustainable Urban Development in Vietnam. Hanoi, 2010.

2. Ibídem.

3. LEMOINE, Jacques; KID-ARN, Kittima; BOODPHETCHARAT, Thanit; SAENMI, Sakda; TILLMAN, Timmi. 'Map of ethnics groups in Vietnam'. IKAP Network for capacity Building in MMSEA. Chiang Mai, 2005.

4. Ibídem.

5. SUZUKI, Haruka. "'Ironwood' utilization and its changes in Vietnam and Indonesia”. 2005.

6. LEMOINE, J.; KID-ARN, K.; et al. Opus cit.

7. NGUYEN, Anh-Tuan; TRAN, Quoc-Bao; TRAN, Duc-Quang; REITER, Sigrid. 'Climate responsive design strategies of vernacular housing in Vietnam'. Building \& Environment. n. 46, 2011. 8. LEMOINE, J.; KID-ARN, K.; et al. Opus cit.

9. Perry-Castañeda Library Map Collection. Austin University, Texas

10. LEMOINE, J.; KID-ARN, K.; BOODPHETCHARAT, T.; SAENMI, S.; TILLMAN, T. Opus cit.

\section{REFERENCES}

CHU, Q.T.; TRUC, K. Dân Gian Truyện Thông Việt Năm. (Traditional Popular Architecture in Vietnam). Hanoi: Fine Arts Publisher, 2004. HOANG, H.A. Cac Loai Nha Truyen Thong: Nha Ruong Classification Traditional Houses. "Ruong" house. Guide to Restore Traditional House (Hue heritage house, 2003). Hue: Thuan Hoa Publisher, 2003. pp. 19-29

NGO, H.Q. Tim Hieu Lich Su Kien Truc Viet Nam: Research of Vietnam Architectural History. Hanoi: Construction Publisher, 2000. PHUONG, Ly; BIRKELAND, Janis; DEMIRBILEK, Nur. 'Applying environmentally responsive characteristics of vernacular architecture to sustainable housing in Vietnam' in Sustainable Architecture \& Urban Development. Amman, Jordania: CSAAR Press, 2010. 